\title{
Effect of Pine (Pinus densifflora) Needle Extracts on Synthesis of Collagen in Osteoblastic MC3T3-E1 Cells
}

\author{
Min Hee Jeon, Young Kyoung Kim, Yong Soo Park, Hyun Jung Hwang, Sung Gu Kim', \\ Sang-Hyeon Lee ${ }^{2}$, In Soon Choi ${ }^{3}$ and Mihyang Kim* \\ Department Food and Nutrition, Silla University, Busan 617-738, Korea \\ ${ }^{1}$ Bioport Korea Co., Busan 619-912, Korea \\ ${ }^{2}$ Department of Bioscience and Biotechnology, Silla University, Busan 617-738, Korea \\ ${ }^{3}$ Department of Biological Science, Silla University, Busan 617-738, Korea
}

Received March 26, 2010 / Accepted April 8, 2010

\begin{abstract}
Osteoporosis is a disease involving a decrease in bone mineral density and an increased risk of fractures. The MC3T3-E1 pre-osteoblastic cell line is a well-accepted model of osteogenesis in vitro. Pine needles have long been used as a traditional health-promoting medicinal food in Korea. In this study, MTT assay, the alkaline phosphatase (ALP) activity and collagen synthesis of osteoblast cells were investigated to determine the effects of pine needle extracts on cell proliferation and differentiation. Pine needle extracts were prepared using hexane, ethanol and water. The effects of the pine needle extracts were examined by comparing the results with those of commercial agents, such as proanthocyanidin. The MC3T3-E1 cells exposed to proanthocyanidin showed increased proliferation in a concentration-dependent manner. The cells exposed to the hexane extract showed a similar increase in proliferation to that observed with proanthocyanidin. The hexane extract showed the highest ALP activity. Moreover, a supplement of pine needle extracts induced collagen synthesis in MC3T3-E1 cells. The pine needle extract produced the highest level of collagen synthesis at concentrations of $10 \sim 50 \mu \mathrm{g} / \mathrm{ml}$. These results indicate that pine needle extracts have an anabolic effect on bone by promoting osteoblastic differentiation, and may be used in the treatment of common metabolic bone diseases.
\end{abstract}

Key words : Pine (Pinus densiflora) needle, MC3T3-E1 cell, MTT assay, alkaline phosphatase, collagen synthesis

\section{서 론}

뼈는 파골 세포에 의한 골 흡수와 그에 따른 조골세포에 의한 새로운 골 기질 형성, 그리고 무기질화 과정이 끊임없이 반복적으로 일어나는 활발한 대사기관이다. 그러나 일반적으 로 폐경 후 에스트로겐이 감소하면서 파골세포에 의한 골 흡 수가 폐경 전에 비해 많아져 빠른 뼈 손실이 일어나고 폐경 이후 10 년 사이에 약 $20 \%$ 의 골 무기질이 감소하는 등[33] 골 대사 질환을 가진다. 대표적인 골 대사 질환 중 고령화 사회에 서 큰 문제로 대두되고 있는 골다공증은 뼈 밀도가 낮아지고 뼈의 조직의 구조가 악화된 것으로 골절을 유발할 수 있는 질병으로 골 형성과 골 흡수의 불균형으로부터 야기되는 퇴행 적인 골 대사 질환이다. 골다공증의 치료는 여성 호르몬 대체 요법, 선택적 에스트로겐 수용체 조절제(SERM), 비스포스포 네이트, 부갑상선 호르몬, 칼시토닌 투여 등으로 알려져 있다 [12]. 현재 골다공증의 예방과 치료에 가장 많이 이용되고 있 는 방법은 에스트로겐이나 천연에 존재하면서 약한 에스트로

\section{*Corresponding author}

Tel : +82-51-999-5620, Fax : +82-51-999-5457

E-mail : mihkim@silla.ac.kr
겐 활성을 나타내는 식물 유래의 phytoestrogen이 폐경 후 골 다공증 예방에 매우 유용하게 처방되고 있다[1]. 조골세포는 골 표면에 근접해 있으며 세포질 내에 과립형질 내 세망이 발달해 있으며, 세포막에는 당단백 효소인 alkaline phosphatase (ALP)가 존재하고 있다[31]. 이 효소는 기질 특이성과 염 기성 $\mathrm{pH}$ 에서 최적의 활성을 나타내고 세포의 외막과 석회화 조직의 기질소포에서 높은 농도로 발견되어 석회화 과정 동안 무기인산의 운반, 세포분열이나 분화의 조절자로서 역할을 하 여[24], 골세포 분화의 표지인자로 알려져 있다[9]. 또한 활성 화된 조골세포는 골 기질을 생성하는데 콜라겐, osteocalcin, osteopontin, bone sialoprotein과 같은 물질을 합성하여 석회 화 과정에 중요한 역할을 한다[20]. 콜라겐은 진피, 인대, 건, 연골, 뼈, 근막, 혈관 등의 결합조직에 광범위하게 분포되어 있으며 체 단백질의 약 $30 \%$ 를 차지하는 중요한 경섬유 단백 질이다[23]. 콜라겐은 estrogen에 의해 생성량이 증가한다는 연구 보고도 있으며[18], 골다공증 및 연골조직의 노화에 의한 골 관절염 병인에 연골조직의 collagen이 손상되고, 구조가 비 정상적으로 변한다고도 보고 되고 있다[22]. 한편, 소나무는 표고 $1000 \mathrm{~m}$ 이하의 국내 어느 지형에서나 자라고 있는 사철 푸른 나무로 우리나라 이외에도 중국, 일본 등 아시아 지역의 
임야에서 널리 자생하고 있다[28]. 솔잎은 예로부터 약용식품 으로 널리 이용되어 왔으며 동의보감에 따르면 중풍, 동맥경 화, 고혈압과 같은 심혈관계질환, 위장질환, 비뇨기질환, 피부 질환, 간장질환, 당뇨, 탈모, 불면증, 신경쇠약 등에 유용한 효 능을 보인다[19]. 솔잎에 대한 선행연구로는 혈행 및 지질개선 의 효과[15], 항산화 효과[10], 항돌연변이 활성[17,22], 항균 효 과 및 항암 활성[5,8,27], 항노화[7]에 대한 보고가 있다. 솔잎 의 주요성분은 querecetin, kaempferol 등의 flavonoid 류, $a-$ oinene, $\beta$-pinene, camphene 등의 정유 성분 및 수지, 당류, carotene, vitamin $C$ 등이 있다[21]. 또한 솔잎 중의 flavonoid 류 중 proanthocyanidin은 항산화력이 우수한 것[10]으로 알 려져 있다.

조골세포의 배양법은 골의 대사, 골세포의 생성 및 분화 등 의 연구와 각종 호르몬이나 성장인자, cytokines가 골 대사에 미치는 효과 그리고 식품유래 천연물질의 골 대사 조절물질을 검색하는데 비교적 간편하면서 유용한 방법으로 알려져 있다 [4,30]. 골조직 유래 확립된 여러 가지 세포주 중 태생기의 마우 스를 이용한 MMBI, MC3T3-E1 골아세포주의 태생기의 rat을 이용한 RCB, RCJ 세포주가 널리 이용된다. 본 연구에 사용한 mouse calvaria 유래의 MC3T3-E1 osteoblastic cell 은 in vivo 골 형성 과정에서 나타나는 세포의 증식, 분화, 석회화 등 골아 세포와 유사한 대사적 특징을 가지고 있으므로, 골세포의 세 포 활성과 관련된 연구에서 유용하게 이용되어 왔다[13,16]. 따라서 본 연구에서는 MC3T3-E1 세포를 이용하여 적송잎 추 출물이 조골세포의 증식에 미치는 영향, 조골세포의 활성과 분화 인자인 ALP 활성 및 조골세포의 골 형성을 위한 필수 인자인 콜라겐 합성에 미치는 영향을 검토하였다.

\section{재료 및 방법}

\section{세포배양}

경희대학교 의과대학 내분비 연구실에서 분양 받은 mouse calvaria osteoblast cell 인 MC3T3-E1 세포는 a-MEM 배지 (Gibco BRL, Grand islane, N. Y., USA)에 10\% FBS (Gibco)와 $1 \%$ antibiotics (Gibco)를 첨가하면서 $37^{\circ} \mathrm{C}, 5 \%$ 의 $\mathrm{CO}_{2}$ incubator에서 2 3일 마다 배지를 교환하면서 실험에 사용하였 다. 분화유도를 위해 $5 \mathrm{mM}$ B-glycerol phosphate (Sigma Chem. Co., St. Louis. Mo., USA)와 $50 \mathrm{mg} / \mathrm{ml}$ 의 vitamin C (Sigma)를 첨가하여 분화유도 배지로 사용하였으며, 3 일마다 배지를 교환하였다.

\section{추출물의 제조}

본 실험에 사용한 적송잎은 2008년 지리산에서 채취하여 $60^{\circ} \mathrm{C}$ 에서 열풍 건조한 후 믹서로 분말화시켜 열수 추출, 에탄 올 추출과 헥산 추출을 행하였다. 열수 추출은 $700 \mathrm{~g}$ 에 물 $4,500 \mathrm{ml}$ 을 첨가하여 $121^{\circ} \mathrm{C}$ 에서 15 분간 추출한 후 여과한 액을
동결 건조하여 제조하였다. 에탄올 및 헥산 추출은 분말 200 $\mathrm{g}$ 에 각각 $95 \%$ 에탄올 및 헥산 $1,500 \mathrm{ml}$ 을 첨가하여 상온에서 24시간 침지하여 추출한 후 여과한 액을 동결 건조하여 제조 하였다. 동결 건조하여 얻은 적송잎 추출물 분말 각각 1,10 , $50,100 \mu \mathrm{g} / \mathrm{ml}$ 를 에탄올로 용해한 후, $0.2 \mu \mathrm{l}$ membrane filter 로 여과한 후 사용하였다.

\section{세포증식 유도}

시료의 농도별 처리에 따른 조골세포의 세포 증식은 Green 등의 방법에 따라 3-(4,5-dimethylthiazol-2-yl)-2,5-diphenyl tetrazolium bromide (MTT, sigma) 시약의 환원 정도를 측정 하는 MTT assay 방법을 사용하여 측정하였다. MTT (3-(4,5dimethylthiazol-2-yl)-2,5-diphenyl tetrazolium bromide) 분 석은 탈수소 효소작용에 의해 노란색의 수용성 기질인 MTT tetrazolium을 청자색의 formazan (3-(4,5-dimethylthiazol-2yl)-2,5-diphenyl tetrazolium bromide)으로 환원시키는 미토 콘드리아의 능력을 이용하는 검사법으로 이 검사법은 세포의 증식과 성장을 알아보는 대표적인 실험방법 중 하나로 살아있 는 세포수에 비례해서 흡광도를 나타낸다. 배양한 MC3T3-E1 세포를 $0.4 \%$ trypan blue 염색법을 이용하여 세포수를 $1 \times 10^{5}$ cell $/ \mathrm{ml}$ 로 조정하여 96 well plate에 platting 한 후, 농도별로 준비된 적송잎 추출물을 $20 \mu 1$ 씩 첨가하여 $37^{\circ} \mathrm{C}, 5 \%$ 의 $\mathrm{CO}_{2}$ incubator에서 48시간 배양하였다. 이때 대조군으로는 적송잎 추출물 대신 에탄올을 $20 \mu \mathrm{l}$ 를 첨가하여 동일하게 배양하였 다. 48 시간 배양 후 MTT $(5 \mathrm{mg} / \mathrm{ml})$ 시약을 $10 \mu \mathrm{l}$ 씩 각각의 well에 첨가하고 $37^{\circ} \mathrm{C}, 5 \%$ 의 $\mathrm{CO}_{2}$ incubator에서 4 시간 더 배 양하였다. 배양 후 배지를 제거하고 DMSO (dimethyl sulfoxide)를 $100 \mu 1$ 씩 첨가하여 생성된 불용성의 formazan 결정 을 용해시킨 뒤 ELASA reader로 $550 \mathrm{~nm}$ 에서 흡광도를 측정 하였으며, 세포 증식률은 적송잎의 흡광도를 대조군의 흡광도 에 대한 백분율로 나타내었다.

\section{Alkaline phosphatase (ALP) 활성}

배양된 MC3T3-E1 세포를 $1 \times 10^{5} \mathrm{cell} / \mathrm{ml}$ 로 조정하여 96 well plate에 platting 한 후, 농도별로 준비된 적송잎 추출물을 $20 \mu \mathrm{l}$ 씩 첨가한 후 $37^{\circ} \mathrm{C}, 5 \%$ 의 $\mathrm{CO}_{2}$ incubator 에서 48 시간 배양하였다. 48 시간 배양 후 $\mathrm{PBS}$ 로 3 회 세척하고 $0.1 \%$ Triton X-100을 $20 \mu 1$ 씩 넣은 다음 $37^{\circ} \mathrm{C}, 5 \%$ 의 $\mathrm{CO}_{2}$ incubator에서 30 분간 lysis 하였다. Lysis 된 cell의 상등액 $5 \mu$ 는 단백질 정량 에 사용하였고, 나머지 상등액에 $20 \mu \mathrm{l}$ 의 $0.1 \mathrm{~N}$ glycine 과 100 ul의 $100 \mathrm{mM}$ p-nitrophenylphosphate (p-NPP)를 첨가한 후 $37^{\circ} \mathrm{C}, 5 \%$ 의 $\mathrm{CO}_{2}$ incubator에서 30 분간 반응시켰다. 반응 후 $0.1 \mathrm{~N} \mathrm{NaOH}$ 로 반응을 정지하고 $200 \mu \mathrm{l}$ 를 취해 $405 \mathrm{~nm}$ 에서 흡광도를 측정하여 ALP 효소에 의해 p-nitrophenol로 전환된 양을 산출하였다. 세포수의 차이가 ALP 활성도에 영향을 미 칠 수 있으므로 총 단백질 양을 측정하여 나누어 줌으로써 
단위 세포수에 대한 ALP 활성도를 계산하였다.

\section{콜라겐 측정 방법}

배양한 MC3T3-E1 세포를 $1 \times 10^{5} \mathrm{cell} / \mathrm{ml}$ 로 조정하여 plate 에 배양한 후 PBS로 2회 세척하고 세포층은 cell scraper를 이 용하여 모은 후 이를 $0.05 \mathrm{M}$ Tris-HCl buffer로 한번 더 현탁 시킨 후 ultrasonicator로 sonication 시켰다. 이후 5\% TCA를 첨가한 후 원심분리하여 상등액을 제거한 뒤 침전물에 $5 \%$ $\mathrm{TCA}$ 를 첨가한 후 이 과정을 2회 반복하였다. 상등액 제거 후 침전물에 $6 \mathrm{~N} \mathrm{HCl}$ 을 가하여 20 시간 동안 $110^{\circ} \mathrm{C}$ 에서 가수분해 하고, 가수분해물을 여과 농축하여 $\mathrm{pH}$ 를 중성으로 조절한 후 실험에 사용하였다. 시료 용액중의 hydroxyproline의 측정은 woessner [36]법을 이용하였고, 얻어진 hydroxyproline량으 로부터 콜라겐량을 환산하였다. 콜라겐 중에 hydroxyproline 이 약 $10 \%$ 포함되어 있으므로, hydroxyproline $(\mathrm{mg} / 100$ $\mathrm{ml}) \times 100 / 11=$ 콜라겐으로 산출하였다.

\section{통계처리}

연구결과 얻어진 자료를 SPSS 통계 프로그램을 사용하여 하위그룹 각각의 기술 통계치(mean, SD)를 산출하였다. 사후 검증은 Tukey를 적용하였고 $p<0.05$ 수준에서 유의수준을 검증 하였다.

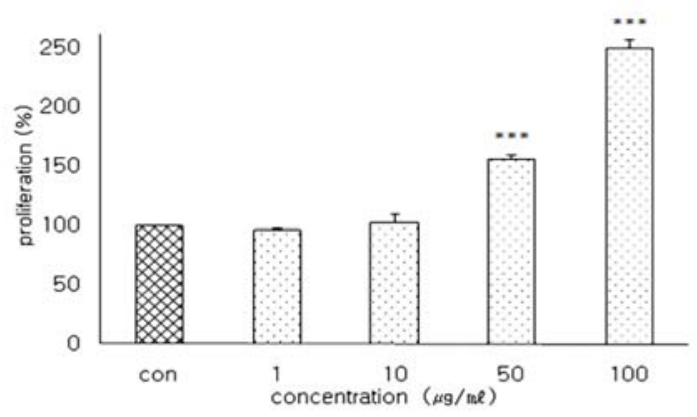

(a) Proanthocyanidin

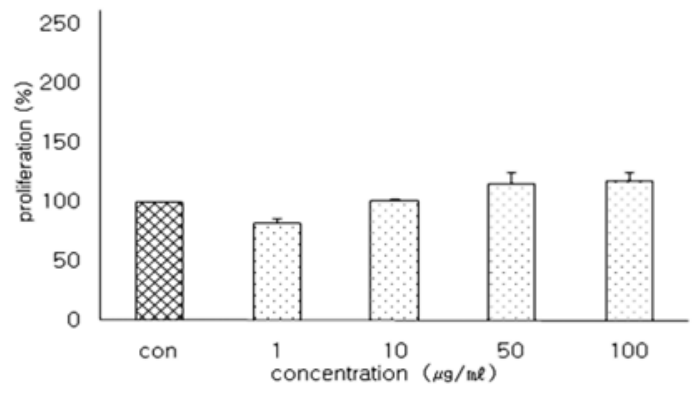

(c) Ethanol extracts

\section{결과 및 고찰}

\section{조골세포에 대한 증식유도 효과}

인체의 뼈는 파골세포와 조골세포에 의해서 지속적인 생성 이 일어난다[32]. 골 세포군의 조골세포[35]는 연골세포, 지방 세포와 같이 간엽 줄기세포에서 유래하며, 조골 전구세포로부 터 분화되어 콜라겐 섬유 등의 골기질 단백질을 합성 - 분비하 고, 자신의 주위로 합성 방출한 유골 속에 묻혀 이 유골에 석회 화가 일어나 골이 형성되면 그 속에 묻혀 골세포가 된다. 조골 세포는 다양한 성장인자를 생성하며 alkaline phosphatase, parathyroid hormone (PHT), 1,25( $\mathrm{OH})_{2} \mathrm{D}_{3}$ 그리고 estrogen 수 용체들을 함유하고 있다[29].

적송잎 추출물의 농도 $(1,10,50,100 \mu \mathrm{g} / \mathrm{ml})$ 에 따른 조골세 포 성장에 미치는 영향을 MTT assay로 분석한 결과는 Fig. 1 과 같다. 적송잎에 함유되어 있으면서 항산화능을 가진 것으 로 알려져 있는 proanthocyanidin 의 조골세포 성장에 미치는 영향을 검토한 결과, 농도 $10 \mu \mathrm{g} / \mathrm{ml}$ 까지는 증식률에 별다른 변화가 나타나지 않았으나 $50 \mu \mathrm{g} / \mathrm{ml}$ 이상 첨가한 군에서 대조 군보다 급격한 증식률을 나타내었다 $(\mathrm{p}<0.001)$. 적송잎 헥산 추 출물 처리군에 있어서는 $10 \mathrm{\mu g} / \mathrm{ml}$ 농도 이상에서 증식률의 증가가 나타났다. 이에 반해 에탄올 추출물을 첨가하였을 때 첨가 농도 증가에 의한 증식 증가는 나타났으나 유의적인 차

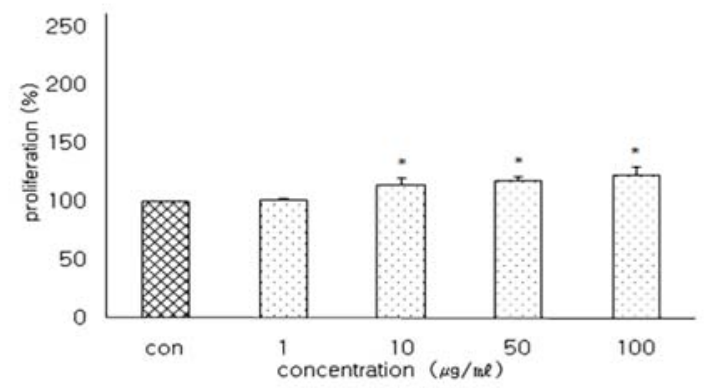

(b) Hexane extracts

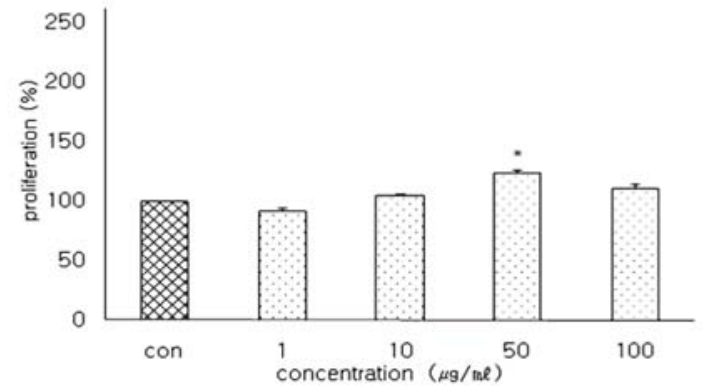

(d) Hot water extracts

Fig. 1. Effect of pine needle extracts on the proliferation of the MC3T3-E1 osteoblastic cells by the MTT assay. ${ }^{*} p<0.05,{ }^{* *} p<0.01,{ }^{* * *} p<0.001$ compared with control 


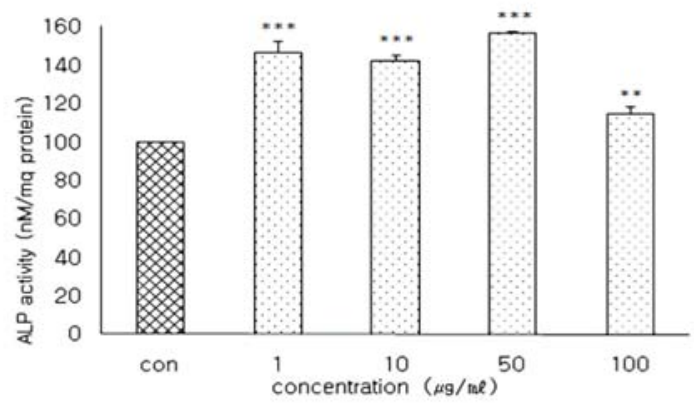

(a) proanthocyanidin

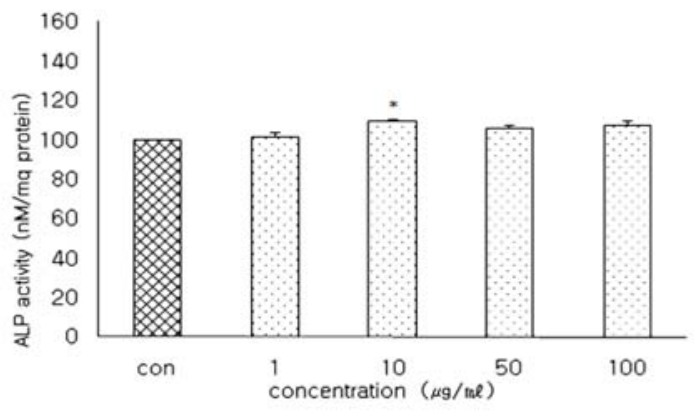

(c) Ethanol extracts

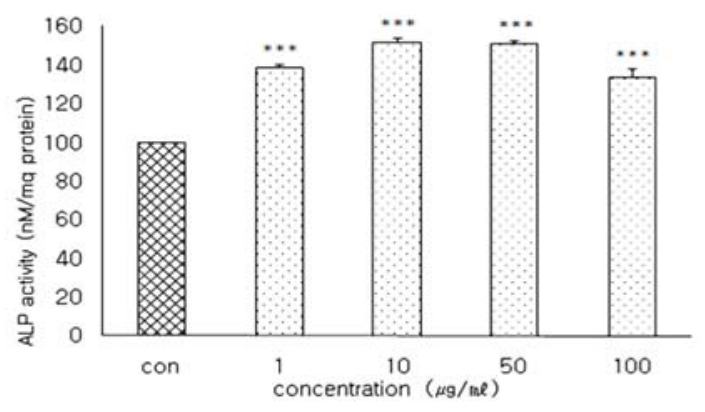

(b) Hexane extracts

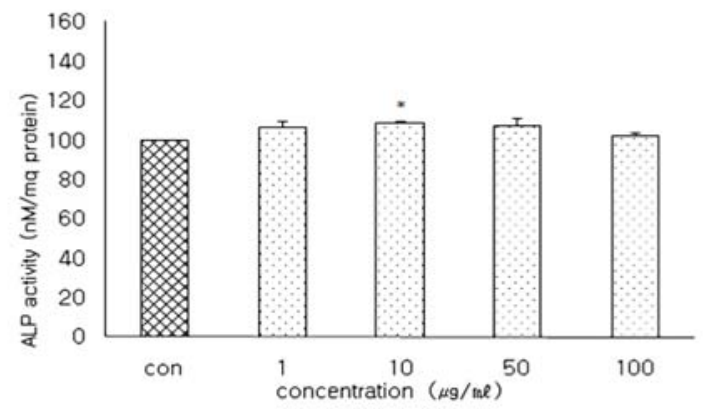

(d) Hot water extracts

Fig. 2. Effect of pine needle extracts on the alkaline phosphatase activities of the MC3T3-E1 osteoblastic cells during the differentiation. ${ }^{*} p<0.05,{ }^{* *} p<0.01,{ }^{* * *} p<0.001$ compared with control

이가 보이지 않은 반면, 열수 추출물의 경우 $50 \mu \mathrm{g} / \mathrm{ml}$ 첨가하 였을 때, $120 \%$ 이상의 증식률을 나타내 유의적인 증식향상이 유도되었다.

대두 에탄올 추출물을 실험한 최[6]의 결과에서는 50 100 $\mu \mathrm{g} / \mathrm{ml}$ 의 농도로 조골 세포주에 처리한 결과 대조군에 비해 최고 $117 \%$ 의 증식률을 나타내었으나, 본 실험결과 적송잎의 $100 \mu \mathrm{g} / \mathrm{ml}$ 헥산 및 $50 \mu \mathrm{g} / \mathrm{ml}$ 열수 추출물 첨가 시 $120 \%$ 이상 의 증식유도 효과가 나타나 더 높은 조골세포 증식유도 결과 임을 확인 할 수 있었다.

\section{Alkaline phosphatase (ALP) 활성에 미치는 영향}

염기성 인산분해 효소(Alkaline phosphatase; ALP)는 거의 모든 조직에 존재하며 특히 골조직에 존재하는 $\mathrm{ALP}$ 는 골 성 장이 활발히 일어날 때 그 활성이 증가한다[14]. 따라서 조골세 포 활성을 나타내는 biomarker [11]로서 MC3T3-E1 조골세포 에서의 ALP 활성을 측정하여 적송잎 추출물이 조골세포의 골 성장 활성에 미치는 영향을 검토하였다.

적송잎 추출물이 ALP 활성에 미치는 영향을 조사한 결과는 Fig. 2에 나타내었다. 조골세포의 ALP 활성은 proanthocyani$\operatorname{din}$ 을 첨가한 경우 $1 \mu \mathrm{g} / \mathrm{ml}$ 이상의 농도에서 증가하였고 100 $\mu \mathrm{g} / \mathrm{ml}$ 농도에서는 대조군과 비교하여 유의성 있는 결과를 나 타내었으나, 오히려 $50 \mu \mathrm{g} / \mathrm{ml}$ 농도보다 감소하는 경향이 나타
났다. 헥산 추출물을 첨가한 경우, $1 \mu \mathrm{g} / \mathrm{ml}$ 이상의 농도에서 유의성 있는 ALP 활성을 나타내었고, proanthocyanidin을 첨 가했을 때와 비슷한 경향을 나타냈다. 한편, 에탄올 추출물의 경우 $10 \mu \mathrm{g} / \mathrm{ml}$ 농도에서 그 활성이 증가하였으나, 그 이상의 농도에서는 오히려 감소하는 경향을 나타내었고, 열수 추출물 에 있어서도 비슷한 결과를 나타내었다.

주로 세포막에 결합되어 존재하는 염기성 인산 분해효소는 기질 특이성과 염기성 $\mathrm{pH}$ 에서 최적의 활성을 나타내는 효소 로써 골세포 분화의 표지인자로 알려져 있다[34]. 따라서 이상 의 결과는 적송잎 추출물이 조골세포의 ALP 의 발현을 증가 시켜 조골세포의 분화에 영향을 줄 가능성을 제시하고 있다. 또한 적송잎의 열수 및 에탄올 추출물보다 헥산 추출물에서 조골세포의 ALP 활성이 증가하여 적송잎의 ALP 활성에 영향 을 주는 성분은 수용성 성분보다 지용성 성분인 것으로 추측 되었다.

\section{조골세포의 콜라겐 합성에 미치는 영향}

골 형성이 이루어지는 과정은 I 형 콜라겐의 합성과 세포내 의 과정 그리고 세포 외로 분비, 섬유질의 형성 및 콜라겐 기질 의 성숙과 hydroxyapatite 형성 등의 단계를 밟는다[37]. 조골 세포에서 합성되는 I 형 콜라겐은 전체 골 단백질의 85 90\% 를 차지하며, 조골세포는 여러 가지 호르몬[2-3,25] 국소인자 


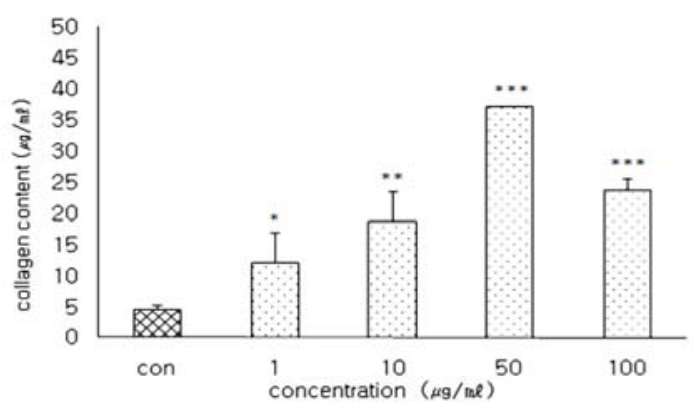

(a) Proanthocyanidin

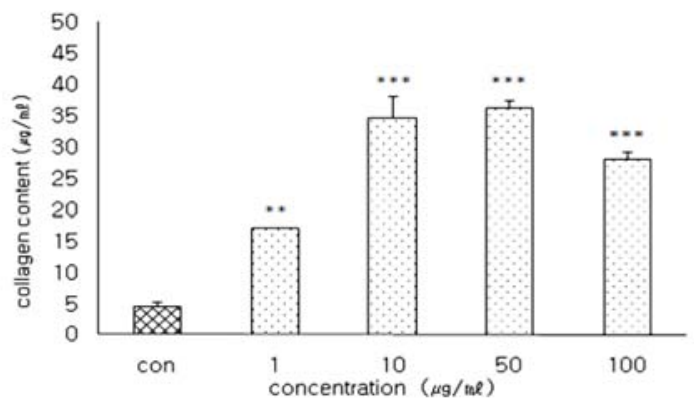

(c) Ethanol extracts

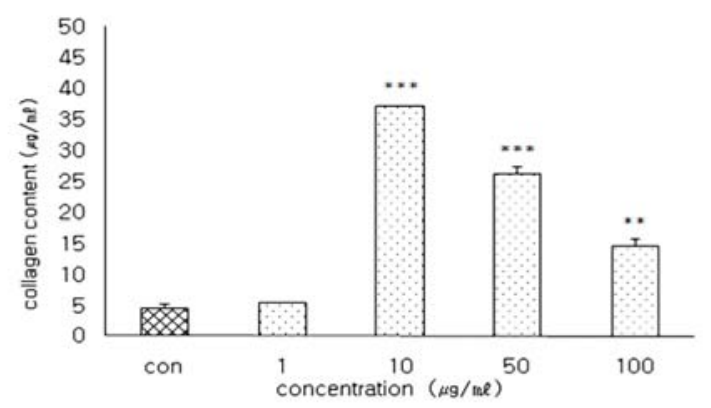

(b) Hexane extracts

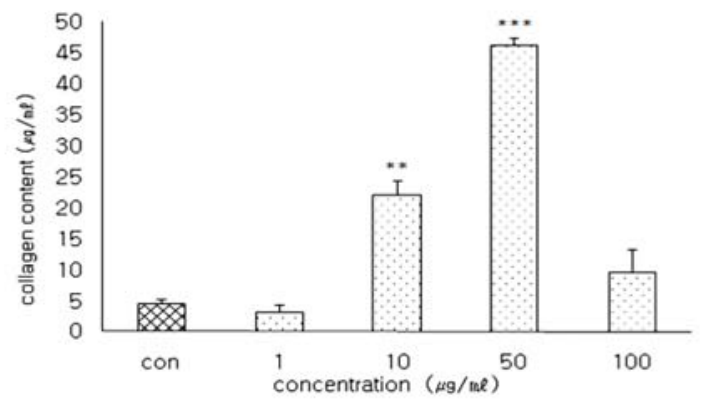

(d) Hot water extracts

Fig. 3. Effect of pine needle extracts on collagen content in bone of the MC3T3-E1 osteoblastic cells. ${ }^{*} p<0.05,{ }^{* *} p<0.01,{ }^{* * *} p<0.001$ compared with control

에 의해 조절되고 있다. 대표적으로 부갑상선 호르몬, 갑상선 호르몬, $1,25(\mathrm{OH})_{2} \mathrm{D}_{3}$, 성호르몬, 인슐린 등이 있고 국소인자로 는 프로스타글란딘과 여러 종류의 cytokine 이 이에 해당된다 [2]. 빼는 주로 콜라겐과 칼슘으로 구성되어 있으며, 계속 성장 하며 살아있는 조직이다. 콜라겐은 빼에서 부드러운 골격을 형성하는 단백질이고 인산칼슘이라는 미네랄이 빼의 골격을 강하고 단단하게 만들어 준다. 또한 콜라겐은 골조직의 유기 물의 대부분을 차지하며, 콜라겐이 적절하게 생성되지 못하는 조건에서는 골조직의 석회화가 일어나지 않을 뿐만 아니라 ALP 활성 저하 및 osteocalcin의 생성 또한 매우 감소하는 것 으로 알려져 있다[26].

Fig. 3은 적송잎 추출물이 조골세포의 콜라겐 합성에 미치 는 영향을 나타낸 것이다. Proanthocyanidin 처리군의 경우 농도 $1 \sim 50 \mu \mathrm{g} / \mathrm{ml}$ 에서는 대조군과 비교하여 농도 의존적으로 콜라겐 합성을 촉진하였고, 농도 $100 \mathrm{\mu g} / \mathrm{ml}$ 첨가군에서는 오 히려 감소하는 결과가 나타났다. 헥산 추출물 처리군은 농도 $10 \mu \mathrm{g} / \mathrm{ml}$ 보다 높을 경우 감소하는 경향을 나타내었으나, 에 탄올 및 열수 추출물의 경우 proanthocyanidin 처리군과 비슷 한 결과를 나타내었다. 특히 열수 추출물을 $50 \mu \mathrm{g} / \mathrm{ml}$ 첨가하 였을 때 대조군에 비해 약 10 배에 해당하는 콜라겐 합성 결과 가 나타났다. 앞선 선행연구[21]에서도 적송잎 추출물 중 proanthocyanidin 함량은 열수 추출물의 경우 $4.5 \mathrm{mg} / \mathrm{g}$ 으로
가장 높은 함량을 나타내었다. 따라서, 이상의 실험결과에서 헥산 추출물뿐만 아니라 열수 추출물에서 높은 콜라겐 합성 능력을 나타낸 것으로 미루어 볼 때, 상이한 화학적 특성을 지닌 proanthocyanidin과 같은 단일성분 또는 복합적 성분들 의 상승 작용에 의해 조골세포의 콜라겐 합성을 촉진시킨 것 으로 추측할 수 있다. 적송잎 추출물이 콜라겐 합성을 촉진하 여 골 생성에 영향을 줄 수 있는 것이 확인되었으며, 그에 대한 구체적인 기작 연구를 위하여 in vivo 및 in vivo 실험을 통한 구체적인 연구가 수행되어야 할 것으로 사료된다.

\section{감사의 글}

본 연구는 교육과학기술부와 한국산업기술진흥원의 지역 혁신인력양성사업으로 수행된 연구결과이며 이에 감사드립 니다.

\section{References}

1. Aldercreutz, H. and W. Mazur. 1996. Phyto-estrogens in relation to cancer and other humam health risks. Proc. Nutr. Soc., 55, 399-417.

2. Canalis, E. 1983. The hormonal and local regulation of bone formation. Endocr Rev. 4, 62-77. 
3. Canalis, E. 1985. Effect of growth factors on bone cell replication and differentiation. Clin Orthop. Related Res. 193, 246-263.

4. Centrella, M., T. L. Mcartht, and E. Canalis. 1987. Transforming growth factor B is a bifunctional regulator of replication and collagen synthesis in osteoblast-enriched cell cultures from fatal rat bone. J. Biol. Chem. 262, 2869-2874.

5. Choi, E. J., C. Lee, T. J. Rhim, B. C. Cha, and H. J. Park. 1997. Antimicrobial activities of pine needle (pinus densiflora) extract. Korean J. Appl. Microbiol. Biotechnol. 25, 293-297.

6. Choi, E. M., K. S. Suh, Y. S. Kim, R. W. Choue, and S. J. Koo. 2001. Soybean ethanol extract increase the function of osteoblastic MC3T3-E1 cells. Phytochemistry 56, 733-739.

7. Choi, J. H., D. I. Kim, S. H. Park, D. W. Kim, J. H. Lee, and H. S. Kim. 2001. Investigation of anti-aging effect and experiment. IV. Effects of butanol fraction on oxygen radicals and their scavenger enzymes in brain of SD rats. Korean J. Gerontol. 11, 7-13.

8. Chung, Y. J., M. W. Bae, M. I. Chung, J. S. Lee, and M. S. Chung. 2002. Cytotoxin effect of the distilled pine-needle extracts on several cancer cell lines in vitro. Korean J. Food Sci. Nutr. 31, 2-13.

9. Dragsted, L. O., M. Strube, and J. C. Larsen. 1993. Cancer-protective factor in fruits and vegetables. Biocheminal and biological background. Pharmacol. Toxicol. 72, 116-135.

10. Hsu, T., S. Sheu, E. Liaw, T. Wang, and C. Lin. 2005. Anti-oxidant ctivity and effect of pinus morrisonicola Hay. on the survival of leukemia cell line U937. Phytomedicine 12, 663-669.

11. Jang, Y. J. 2008. Effects of Acanthopanax senticosus vat. Subinermis (ASVS) leaf extract on promoting cell proliferation, differentiation, mineralization and osteogenesis-related gene expression in ROS 17/2.8 cells. Department of Food and Nutrition. Graduate School, Younsei University. M. S. thesis, Korea.

12. Jilka, R. L. 1998. Cytokines, bone remodeling and estrogen deficiency: a 1998 update. Bone 23, 75-81.

13. Kalu, D. 1991. The ovariectomized rat model on postmenopausal bone loss. Bone and Mineral 15, 175-192.

14. Kang, S. R. 2009. Effect of ecklonia cava extracts on lipids and bone turnover markers in menopausal women. Department of Food Nutrition. Graduate School, Silla University. M. S. thesis, Korea.

15. Kang, S. R., Y. K. Kim, S. G. Kim, S. H. Lee, and M. H. Kim. 2009. The Effect of Pine (pinus densiflora) Needle Extracts on Blood Flow and Serum Lipid Improvement. J. Life Science 19, 508-513.

16. Kimble, R. B., J. L. Vannice, and D. C. Bloedow. 1994. Interleukin- I receptor antagonist decrease bone loss and resorption in ovariectomized rats. J. Clin. Invest. 93, 19591967.

17. Kim, E. J., K. P. Choi, S. S. Ham, and H. Y. Kang. 1998. Inhibitory effect of pine needle extracts on the chemical induces mutagenicity. Korean J. Food Sci. Technol. 30, 450-455.

18. Kim, E. J., S. W. Jung, K. P. Chio, and S. S. Ham. 1998. Cytotoxic effect of the pine needle extracts. Korean J. Food
Sci. Technol. 30, 213-217.

19. Lee, H. J. 2004. Studies on biological activities of the pine-needle distilled water extract. School of Biotechnology and Bioengineering Graduate School, Kangwon National University. M. S. thesis, Korea.

20. Lee, J. W. 2004. Effect of Solidago Virga-aurea var. giagantea Mig. Root extract on the activity of osteoblastic cells and bone metabolism. Department of Food Science and Technology, Graduate School of Keimyung University, Daegu, Korea. M. S. thesis, Korea.

21. Lee, O. H. K. Y. Kim, M. K. Jang, K. H. You, S. G. Kim, M. H. Kim, and S. H. Lee. 2008. Evaluation of proanthocyanidin contents in total polyphenolic compounds of pine (pinus densiflora) needle extracts and their antioxidative activities. J. Life Science 18, 213-219.

22. Lee, Y. H., Y. S. Choi, and S. Y. Lee. 1996. The cholesterol-lowering effects of the extract from Pinus strobus in chickens. Korean J. Soc. Food Nutr. 25, 188-192.

23. Manolagas, S. C. 2000. Basic regulatory mechanisms and implications for the pathogenesis and treatment of osteoporosis. Birth and death of bone cells. Endocr. Rev. 21, 115-137.

24. Newmark, H. L. 1996. Plant phemolics as potential cancer prevention agents. Adv. Exp. Med. Biol. 401, 25-34.

25. Noriyoshi, K., I. Seichi, K. Mamoru, H. Yoshiyuki, I. Katsumi, and K. Masuoshi. 1986. Effect of 1,25-dihydroxyvitamin $\mathrm{D}_{3}$ on osteoblastic MC3T3-E1 cell. Endocrinology 118, 940-947.

26. Owen, T. A., M. Aronow, and V. Shahoub. 1990. Progressive development of the rat osteoblast phenotype in vitro: relationships in expression of genes associated with osteoblast proliferation and differentiation during formation of the bone extracellular matrix. J. Cell Physiol. 143, 420-430.

27. Pack, C. S. 1998. Antibacterial activity of ethanol extract of pine needle against pathogenic bacteria. Korean J. Postharvest Sci. Technol. 5, 380-385.

28. Park, G. Y., H. S. Lee, I. D. Hwang, and H. S. Jung. 2006. The functional effects of fermented pine needle extract. Korean J. Biotechnol. Bioeng. 21, 376-383.

29. Park, H. M. 1995. Role of systemic hormones and local factors in regulation of bone remodeling. Korean J. Medical Association 38, 8-19.

30. Pfeilschifter, J. and O. Wolf. 1990. Chemotactic response of osteoblastic cells to transforming growth factor B. J. Bone Miner. Res. 5, 815-823.

31. Shin, H. K. 1997. The development of functional food and research trends. Food Sci. and Industry 30, 2-13.

32. Shin, J. M., C. K. Park, E. J. Shin, T. H. Jo, and I. K. Hwang. 2008. Effects of scutellaria radix extracts on osteoblast differentiation and osteocalst formation. Korean J. Food Sci. Technol. 40, 674-679.

33. Solt, D. B. 1991. The pathogenesis, oral manifestations, and implications for dentistry of metabolic bone disease. Curr. Opin. Dent. 1, 783-791.

34. Stein, G. S., J. B. Lian, A. J. van Wifnen, and M. Montechino. 1996. Transcriptional control of osteoblast growth and differentiation. Physiol. Rew. 76, 593-629.

35. Wlodarski, K. H. 1990. Properties and origin of osteoblast. 
Clin. Orthop. Relat. Res. 252, 276-293.

36. Woessner, J. F. 1961. The determination of hydroxyproline in tissue and protein sample containing small proportion of this imino acid. Arch. Biochem. Biophys. 93, 440-447.
37. Yoon, H. G., J. T. Woo, J. W. Kim, Y. S. Kim, K. Y. Kim, Y. K. Choi, and K. S. Seo. 1993. Osteoblastic cell line MC3T3-E1 cell to the triiodothyronine. Korean J. Medicine 44, 49-58.

\section{초록 : 적송잎 추출물이 조골세포의 collagen 합성에 미치는 영향}

전민희 $\cdot$ 김영경 $\cdot$ 박용수 $\cdot$ 황현정 $\cdot$ 김성구 ${ }^{1} \cdot$ 이상현 $^{2} \cdot$ 최인순 ${ }^{3} \cdot$ 김미향*

(신라대학교 식품영양학과, ${ }^{1}$ (주)바이오포트코리아, ${ }^{2}$ 신라대학교 생명공학과, ${ }^{3}$ 신라대학교 생물과학과)

솔잎은 항산화력이 우수한 것으로 알려져 있으며, mouse calvaria 유래의 MC3T3-E1 osteoblastic cell은 골세포 의 세포 활성과 관련된 연구에서 유용하게 이용되어왔다. 따라서 본 연구에서는 MC3T3-E1 세포를 이용하여 적 송잎 용매별 추출물이 세포 증식에 미치는 영향과 ALP 활성 및 조골세포의 골 형성을 위한 필수 인자인 콜라겐 합성의 영향에 대해 검토하였다. 적송잎 추출물의 농도 $(1,1050,100 \mathrm{\mu g} / \mathrm{ml})$ 에 따른 조골세포 성장에 미치는 영 향을 MTT assay로 분석한 결과, proanthocyanidin의 경우 $50 \mu \mathrm{g} / \mathrm{ml}$ 이상 첨가한 군에서 대조군보다 급격한 증 식률을 나타내었다. 에탄올 추출물을 첨가하였을 때 유의적인 증식률이 나타나지 않은 반면, 적송잎 헥산 추출물 처리군에 있어서는 $10 \mu \mathrm{g} / \mathrm{ml}$ 농도 이상에서 유의적으로 세포증식이 촉진되었다. 적송잎 추출물이 ALP 활성에 미치는 영향을 조사한 결과, 적송잎 추출물이 조골세포의 $\mathrm{ALP}$ 의 활성을 증가시켜 조골세포의 분화에 영향을 줄 가능성이 제시 되었다. 또한 적송잎의 열수 및 에탄올 추출물보다 헥산 추출물에서 조골세포의 ALP 활성이 증가 하여 적송잎의 ALP 활성에 영향을 주는 성분은 수용성 성분보다 지용성 성분인 것으로 추측되었다. 적송잎 추출 물이 조골세포의 콜라겐 합성에 미치는 실험결과에서 헥산 추출물뿐만 아니라 열수 추출물에서도 높은 콜라겐 합성능력을 나타내었다. 따라서 단일성분에 의한 것보다 복합적 성분들의 상승작용에 의해 조골세포의 콜라겐 합성이 촉진된 것으로 추측할 수 있다. 적송잎 추출물이 조골세포의 증식, ALP 활성 및 콜라겐 합성을 촉진하여 골 생성에 영향을 줄 수 있는 것이 확인되었으며, 그에 대한 구체적인 기작 연구를 위하여 향후 분자생물학적인 차원에서의 in vitro 및 in vivo 실험을 통한 구체적인 연구가 수행되어야 할 것으로 사료된다. 